\title{
Oral Cytokeratins in Health and Disease
}

\author{
${ }^{1}$ Roopa S Rao, ${ }^{2}$ Shankargouda Patil, ${ }^{3}$ BS Ganavi
}

\begin{abstract}
The dynamics of oral mucosa is known by its inherent defensive nature. Certain areas demand tough shield when subjected to mechanical insults. This is met by structural scaffolding material referred as cytoskeleton comprised of intracellular protein filaments called cytokeratins in the surface squames of oral epithelia. They also equally contribute towards the architecture of odontogenic apparatus and salivary gland. Differentiation of epithelial cells within stratified epithelia regulates the expression of specific keratin gene. Any mutation in, or autoantibodies to keratins, desmosomal and cornified envelope proteins is translated into genetic and acquired human disorders. Sound knowledge of structural proteins, their expression, distribution and function plays a vital role in acquainting with these disorders and their application as differentiation markers. Thus, they form an integral aid in diagnostic pathology and may be instrumental in the future interventions by gene therapy. This review focuses on basics to current updates on oral cytokeratins with an emphasis on the genetic and acquired disorders of cytokeratins with oral implications.
\end{abstract}

Keywords: Cytokeratins, Cytokeratin markers, Keratin genes, Keratin disorders.

How to cite this article: Rao RS, Patil S, Ganavi BS. Oral Cytokeratins in Health and Disease. J Contemp Dent Pract 2014;15(1):127-136.

Source of support: Nil

Conflict of interest: None declared

\section{INTRODUCTION}

Oral epithelium has regional diversity corresponding to functional needs as it is subjected to different forms and intensity of stress which demand tougher epithelial cells. Thus, this need is met by the formation of intracytoplasmic filamentous arrays called keratins. 'The keratins' are most diverse and an outstanding group of proteins belonging to the intermediate filament (IF) family which constitute about $80 \%$ of the total protein content in differentiated cells of stratified epithelia. ${ }^{1-3}$

${ }^{1}$ Professor and Head, ${ }^{2}$ Associate Professor, ${ }^{3}$ Postgraduate Student

${ }^{1-3}$ Department of Oral Pathology and Microbiology, Faculty of Dental Sciences, MS Ramaiah University of Applied Sciences MSRIT Post, MSR Nagar, Bangalore, Karnataka, India

Corresponding Author: Shankargouda Patil, Associate Professor, Department of Oral Pathology and Microbiology Faculty of Dental Sciences, MS Ramaiah University of Applied Sciences, MSRIT Post, MSR Nagar, Bengaluru-560054 Karnataka, India, e-mail: dr.ravipatil@gmail.com
The word keratin comes from the Greek word 'kera' meaning horn. ${ }^{4}$ Keratins are defined as intermediate filament forming proteins, (10 $\mathrm{nm}$ in diameter) with specific physicochemical properties, produced in any vertebrate epithelia. ${ }^{5}$ They form the cytoskeletal structural proteins of stratified keratinizing epithelia. ${ }^{6}$

\section{HISTORY}

A century ago in 1850, the word 'keratin' first appeared in literature to denote a material that constituted the hard tissues like animal horns and hooves. ${ }^{4}$ William T Astbury and Francis Crick contributed to the structure of keratin, following which Sun and Green popularized the monoclonal keratin antibodies. The identification of types I and II subunits in keratin and requirement of both these types to constitute a stable keratin assembly was noted by Fuchs and co-workers. All these developments were followed by extensive research in biology and pathology using monoclonal antibodies with the discovery of Epidermolysis bullosa simplex (EBS) as the first disease of IF. ${ }^{7}$

\section{KERATINIZATION IN ORAL EPITHELIA}

Oral epithelia demonstrate one of the 2 patterns of epithelial maturation (Fig. 1). ${ }^{2}$

1. Keratinization - mucosa matures by formation of surface layer of keratin.

a. Orthokeratinization - refers to the absence of nuclei in the surface layer of squames on maturation.

b. Parakeratinization-refers to the retention of pyknotic nuclei in the surface layer of squames on maturation. $^{2}$

2. Nonkeratinization - refers to maturation with absence of keratin layer. Hence the surface cells retain their nuclei with sparse keratin filaments in the cytoplasm. ${ }^{8}$

Meeting the functional demands, gingiva demonstrates both types of epithelia-keratinized (e.g. Attached and free gingiva) and nonkeratinized (e.g. Sulcular and junctional epithelia). ${ }^{2}$

The following terms denote pathologic states:

- Keratosis: When keratinization occurs in a normally nonkeratinized tissue, it is referred to as keratosis.

- Parakeratosis: When normally keratinizing tissue, such as epidermis, becomes parakeratinized, it is referred to as parakeratosis. ${ }^{9}$ 


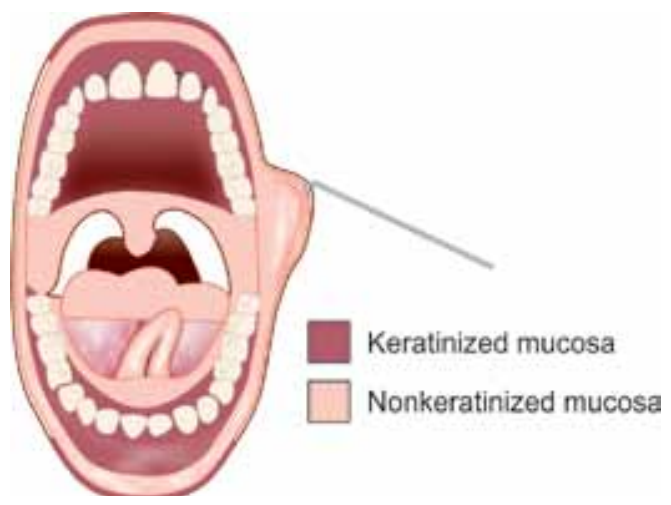

Fig. 1: Keratinization in oral mucosa

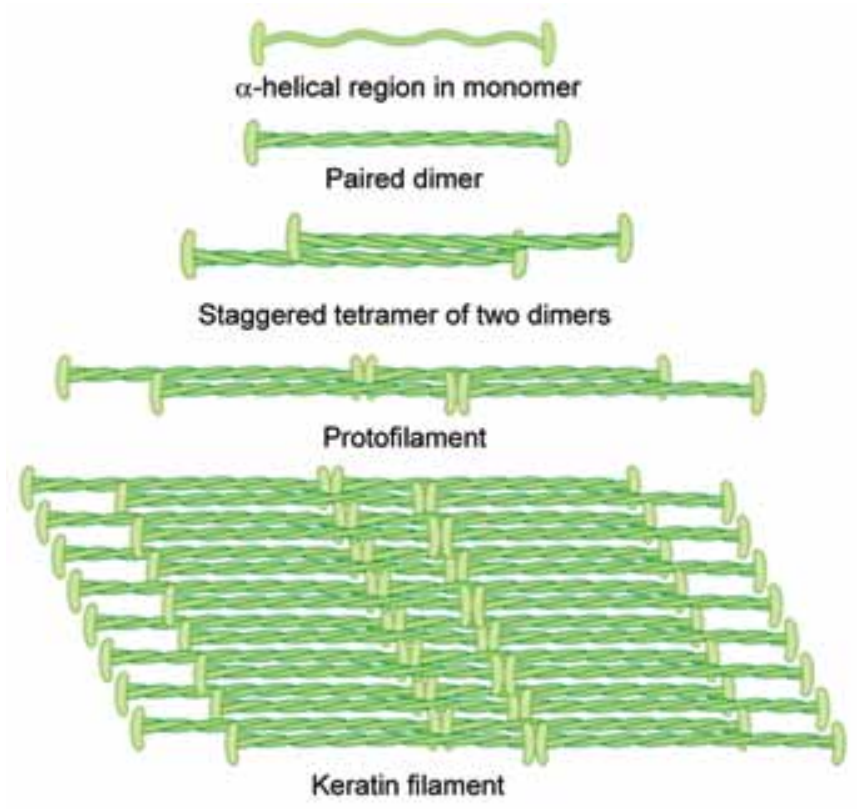

Fig. 2: Assembly of keratin filament

\section{FACTORS INFLUENCING EPITHELIAL DIFFERENTIATION}

Debbie Tudor et al in 2004 reviewed all the experimental evidence on the 'Intrinsic Patterns of Behavior of Epithelial Stem Cells' and concluded that the intrinsic property of epithelial stem cells and mesenchymal modulation of stem cells determine the epithelial phenotype. In addition, mesenchymal modulation of the basic stem and amplification pattern is essential to produce and maintain most epithelial structures. ${ }^{10}$

Retinoids and calcium also influence the normal terminal differentiation of epithelium. Vitamin A and its analogs, retinoids affect the gene expression by a group of nuclear receptor proteins. ${ }^{11}$ Deficiency of vitamin A leads to squamous metaplasia and epithelial keratinization whereas, excess vitamin A inhibits keratinization. ${ }^{12}$ Also, high calcium concentrations are necessary for stratification and desmosome assembly. ${ }^{11}$

\section{KERATIN STRUCTURE}

Keratins are obligate heterodimer proteins, expressed in pairs of types I and II proteins. ${ }^{13}$ The molecular weight of human keratins ranges from 44 to $66 \mathrm{kDa}^{1}{ }^{1}$

Filament assembly begins by parallel association of a type I chain with its type II counterpart to form a paired dimer. Two such paired dimers associate in an antiparallel fashion to form a staggered tetramer. Two tetramers pack together laterally to form the protofilament. Eight such protofilaments are twisted into a rope which forms the keratin filament. Each individual keratin filament therefore has a cross section of 32 individual $\alpha$ helical coils. Strong lateral hydrophobic interactions stabilize the polypeptide chains. Keratin filaments are subsequently bundled and assembled into macromolecular networks that radiate throughout the cytoplasm (Fig. 2). ${ }^{14,15}$

\section{BASIC MOLECULAR STRUCTURE OF KERATIN POLYPEPTIDE CHAINS}

All keratin molecules contain a central rod domain of 310 aminoacids with $\alpha$-helical conformation. This central core is made up of four subdomains $(1 \mathrm{~A}, 1 \mathrm{~B}, 2 \mathrm{~A}, 2 \mathrm{~B})$ separated by three nonhelical linker sequences (L1, L2 and L3) (Fig. 3A). Diversity among keratin filaments resides in nonhelical extensions at the amino and carboxy terminals $(\mathrm{H}, \mathrm{V} \text { and } \mathrm{E} \text { end domains })^{15-18}$ Further, there are two highly conserved helix boundary sequence motives on each rod, called helix initiation peptide (HIP) in the 1A domain and the helix termination peptide (HTP) at the end of helix 2B. Any mutations in these regions, lead to more severe disease phenotypes than the other regions (Fig. 3B). ${ }^{19}$

Glycine is the most abundant residue in cytokeratins. The heads and/or tails of epidermal keratins are glycine and phenylalanine rich but alanine poor and those of simple-type epithelial keratins are enriched in acidic and/or basic residues. ${ }^{20}$

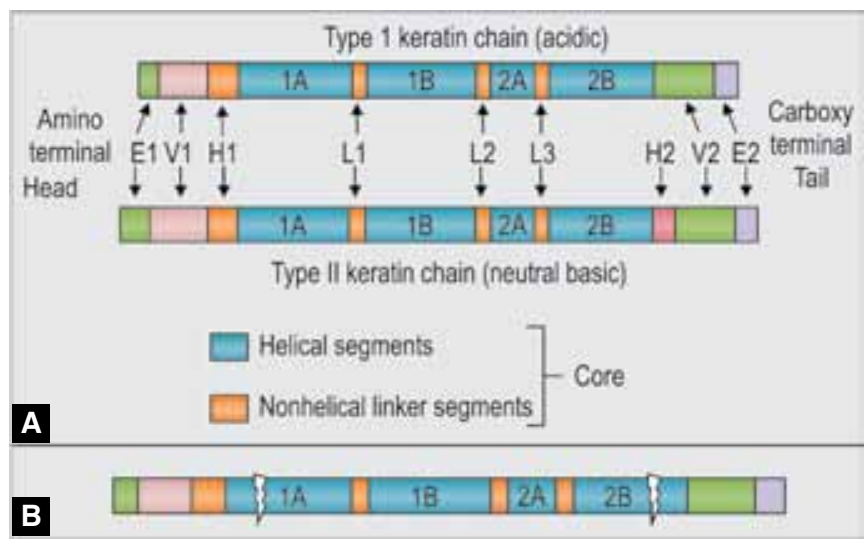

Figs 3A and B: (A) Molecular structure of type I and II keratin, (B) Regions of 'hot spot' mutations in keratin (I) 


\begin{tabular}{|c|c|c|c|}
\hline Class of KFAP & Example & Description & Significance \\
\hline Class I & Filaggrin & $\begin{array}{l}\text { - Low molecular weight, cationic protein that binds } \\
\text { the keratin in tight arrays. } \\
\text { - Synthesized in the granular layer and stored in } \\
\text { keratohyalin granules. } \\
\text { - Converted to filaggrin upon transition of granular } \\
\text { cells tocornified cells. } \\
\text { - Functions: Aggregates and aids keratin filaments in } \\
\text { dense packing within the cornified layer. }\end{array}$ & $\begin{array}{l}\text { Marker to distinguish } \\
\text { nonkeratinized epithelia } \\
\text { from keratinized } \\
\text { epithelia. }\end{array}$ \\
\hline Class II & Trichohyalin & $\begin{array}{l}\text { - High molecular weight and binds keratin in loose } \\
\text { network arrays. } \\
\text { Expressed in keratinizing papillae of the tongue, nail } \\
\text { matrix, new born fore skin epidermis. } \\
\text { Functions: Intercellular cementing, cross bridging } \\
\text { the proteins, regulation of calcium dependent } \\
\text { enzymes }\end{array}$ & \\
\hline \multirow[t]{2}{*}{ Class III } & Loricrin & $\begin{array}{l}\text { Expressed in the superficial layers of keratinized } \\
\text { and nonkeratinized oral epithelia } \\
\text { Function: Binds to the ends of keratin and } \\
\text { contributes towards cornification }\end{array}$ & $\begin{array}{l}\text { Markers to determine } \\
\text { the extent of cell } \\
\text { differentiation. }\end{array}$ \\
\hline & $\begin{array}{l}\text { Desmosomal } \\
\text { proteins }\end{array}$ & $\begin{array}{l}\text { They include integral proteins (desmoglein and } \\
\text { desmocollin), cytoplasmic adapter proteins } \\
\text { (desmoplakin and plakoglobin) and plaque } \\
\text { associated proteins (plakophilin, envoplakin and } \\
\text { periplakin). } \\
\text { Function: Bind epithelial cells and help in } \\
\text { attachment of keratin intermediate filament to cell } \\
\text { surface. }\end{array}$ & $\begin{array}{l}\text { Antibodies to } \\
\text { desmosomal proteins } \\
\text { are demonstrable in } \\
\text { autoimmune diseases } \\
\text { like pemphigus. }\end{array}$ \\
\hline
\end{tabular}

\section{KERATIN FILAMENT ASSOCIATED PROTEINS (KFAPS)}

KFAPs are nonfilamentous, structural proteins that interact with keratin filaments. They are produced in the keratinocytes of the stratum granulosum and stored in keratohyalin granules. KFAPs are needed for the function of the intermediate filament network and for the shape, stability, and motility of epithelial cells. ${ }^{11}$

There are three classes of KFAPs. A brief description and clinical relevance of KFAPs expressed in oral epithelia are collated in Table 1.,11,21-23

\section{Involucrin, Transglutaminase}

Involucrin is yet another KFAP, by enzymatic crosslinking via a particulate transglutaminase is involved in the formation of cornified cell envelope (CCE). They are present in buccal and palatal epithelia and are useful markers of cell differentiation. ${ }^{6}$

\section{KERATIN GENES}

In 2006, Schweizer et al developed a new consensus nomenclature for hard and soft keratins, which includes the highest number of members in humans with 54 distinct functional genes: 28 type I keratin genes (17 epithelial keratins and 11 hair keratins) and 26 type II keratin genes
(20 epithelial keratins and 6 hair keratins). The keratin genes are located at two different chromosomal sites: chromosome 17q21.2 (type I keratins, except K18) and chromosome 12q13.13 (type II keratins including K18) in humans. The keratin genes are designated as KRT1, KRT2, KRT3, etc. ${ }^{24}$

\section{CLASSIFICATION OF KERATINS}

A working classification of keratins based on various criteria is proposed in the Flow Chart 1. ${ }^{1,21}$

\section{FUNCTIONS OF KERATINS}

Keratins primarily serve as the backbone of vertebrate epithelial cells. In addition, keratins serve diverse functions as represented in the Flow Chart 2. ${ }^{19,25}$

\section{DEMONSTRATION OF KERATINS}

Various routine, special and fluorescent stains may be used to demonstrate cytokeratins in histological sections (Table 2). ${ }^{26,27}$

Other staining methods include Dane-Herman method, Schiff reagent after oxidation with performic acid, aldehyde fuchsin, levafix red violet. ${ }^{27,28}$ Immunohistochemical staining is the golden tool for cytokeratin demonstration which is discussed later in this article. 
Table 2: Various histological stains for demonstration of keratin

\begin{tabular}{ll}
\hline Stain & Result \\
\hline Hematoxylin and eosin stain & Pink \\
Ayoub-Shklar stain & Brilliant orange \\
Phloxine-tartrazine method & Red \\
Modified PAP stain & Magenta pink \\
Gram stain & Blue \\
Aldehyde fuchsin technique & Purple \\
Congo red method & Orange-red \\
Performic acid- Methylene blue/ alcian blue technique & Blue \\
Thioflavin T fluorescent technique & Yellow fluorescence \\
Auramine- Rhodamine fluorescent method & Yellow fluorescence \\
\hline
\end{tabular}

Flow Chart 1: Classification of keratin

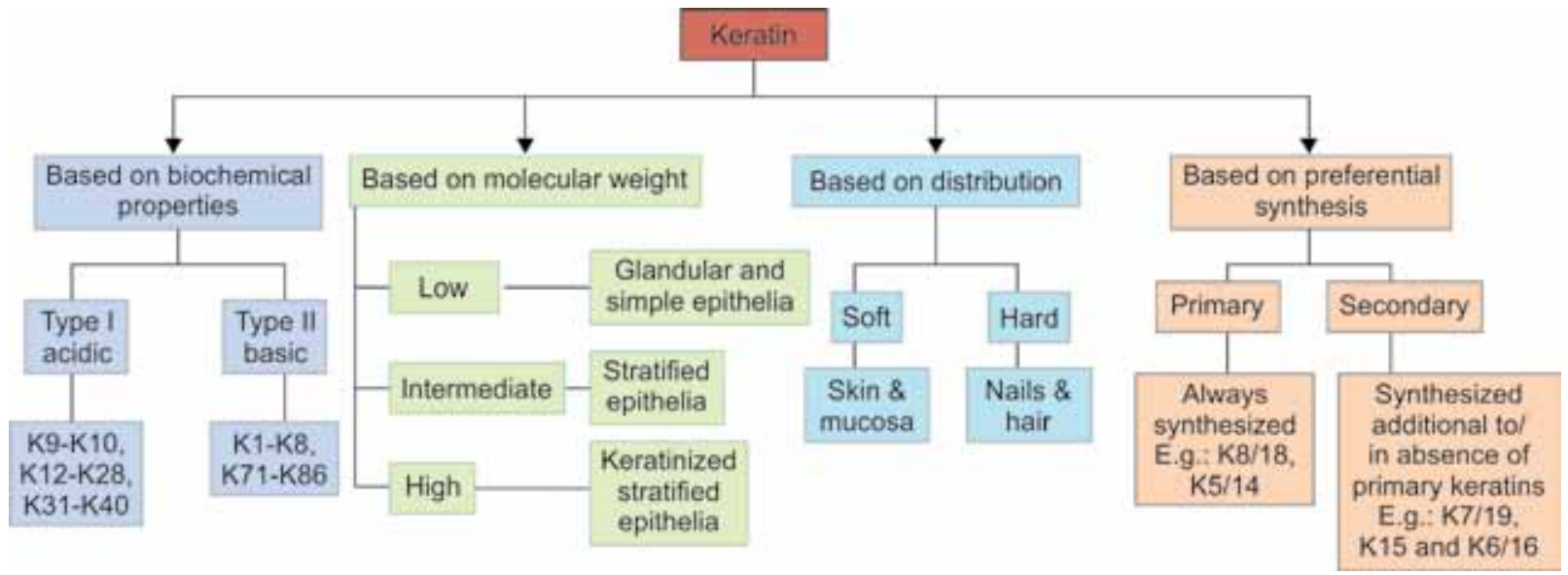

\section{CYTOKERATINS}

Mammalian keratins are subdivided into two distinct groups based on their structure, function and regulation. Cysteinerich keratins are tougher in nature and constitute the 'hard' keratins found in epidermal appendages (hair and nails), whereas loosely packed bundles of cytoplasmic keratin filaments in epithelial cells are termed as 'soft or cyto' keratins. ${ }^{29-31}$

Cytokeratins are the basic structural proteins of epithelial cells. They are abundant in oral cavity, salivary gland epithelia and are expressed during odontogenesis. Also, cytokeratins are the leading biomarkers in diagnostic pathology.
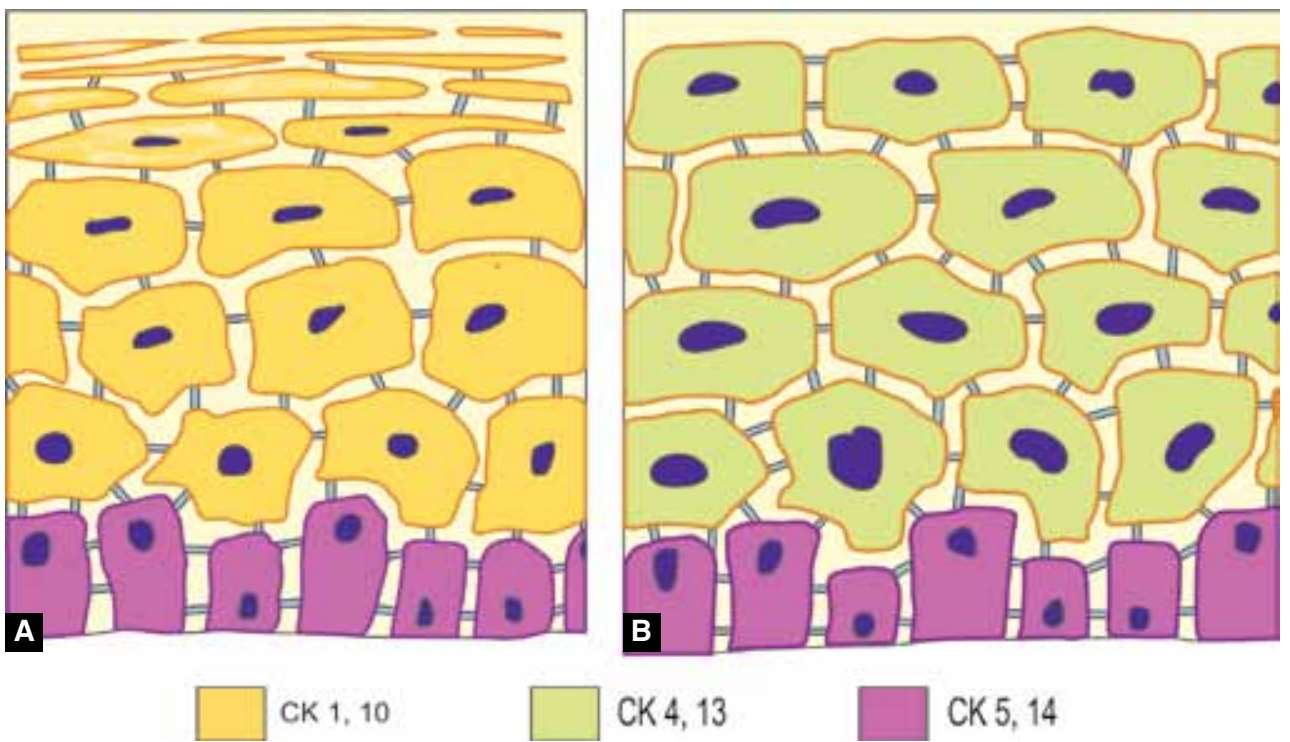

Figs 4A and B: Normal cytokeratin distribution in oral mucosa: (A) Keratinized epithelia, (B) non-keratinized epithelia 


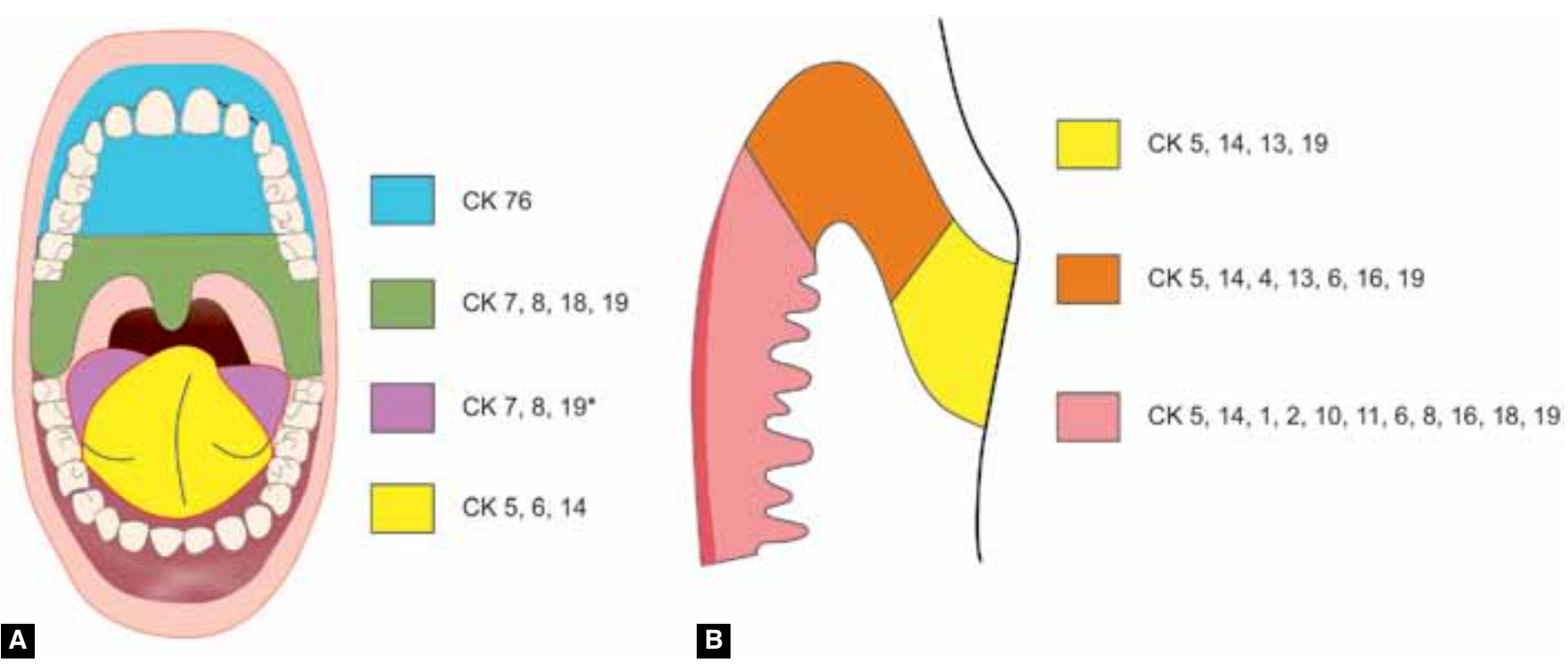

Figs 5A and B: (A) Regional variation in keratin distribution in normal oral mucosa,

(B) cytokeratin distribution patterns in normal gingiva. *Expressed by taste buds

Flow Chart 2: Functions of keratin

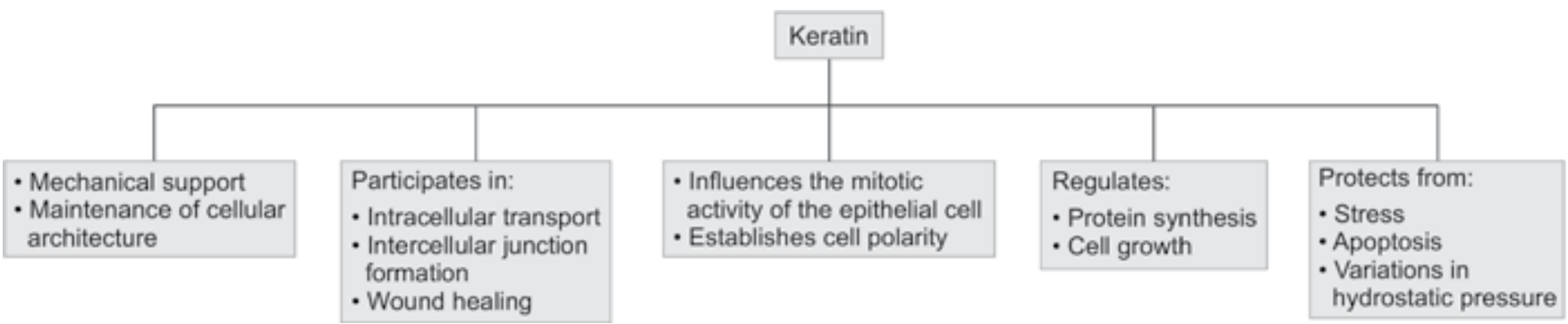

\section{CYTOKERATIN DISTRIBUTION}

Cytokeratin distribution is highly specific and varies with site, type of epithelium and extent of differentiation. ${ }^{1}$ Hence keratin expression is a sensitive and specific marker for assessment of differentiation in epithelial cells.

\section{Cytokeratin Distribution in Normal Oral Epithelia}

Cytokeratin distribution in normal oral epithelia is represented in Figures 4A and B. ${ }^{9} 11,15$

Further, the regional specificity of keratin expression may be attributed to intrinsic specialization of regional keratinocyte stem cells. ${ }^{32}$ Figures $5 \mathrm{~A}$ and $\mathrm{B}$ depict the regional variation in cytokeratin distribution in oral mucosa and gingiva. ${ }^{1,2,9,15}$

Also, CK7, 8, 18, 19 are the markers for simple epithelia and merkel cells. Hyperproliferative epithelia are known to express CK6, 16. ${ }^{11,15}$

\section{Cytokeratin Distribution in Salivary Epithelia and Odontogenic Tissues}

Cytokeratin distribution in salivary epithelia and odontogenic tissues is briefed in Table 3.,33-36 The typical intermediate filament of odontogenic epithelium is CK14, observed in the dental lamina, the reduced enamel epithelium and in almost all cells of the enamel organ except for preameloblasts and secreting ameloblasts. ${ }^{33}$

\section{DISORDERS OF KERATIN}

The field of cytokeratins has scope for exhaustive research and this is due to increasing number of new diseases being explored. Disorders in keratin may be genetic or acquired. Since the discovery of the first genetic disorder of keratin epidermolysis bullosa simplex (EBS), numerous keratin mutations are being identified as cause of several skin and mucosal disorders. Also, abnormal keratinization is part of several acquired oral diseases. A working classification of oral keratin disorders is depicted in Flow Chart 3.

\section{GENETIC DISORDERS OF KERATIN}

A wide array of keratin disorders is attributable to mutations in various genes and majority are result of point mutations. ${ }^{6}$ They may exhibit abnormality in both cyto (soft) and hard keratins. Also, the defective genes may be located within (e.g.: Epidermolysis bullosa simplex, Pachyonychia congenita) or outside the $\alpha$-helical rod domain (Nonepidermolytic palmoplantar keratoderma). In addition, 
Table 3: Cytokeratin distribution in salivary epithelia and odontogenic tissues

\begin{tabular}{|c|c|}
\hline Cytokeratins & Distribution \\
\hline \multicolumn{2}{|l|}{ Salivary epithelia } \\
\hline CK 14 & $\begin{array}{l}\text { Myoepithelial cells and basal cells } \\
\text { (ductal nonluminal cells) }\end{array}$ \\
\hline CK 18,19 & Epithelium elements of salivary gland \\
\hline CK $7,8,18,19$ & Luminal duct cells \\
\hline CK 8,18 & $\begin{array}{l}\text { Epithelium of striated and intercalated } \\
\text { ducts }\end{array}$ \\
\hline \multicolumn{2}{|c|}{ Odontogenic tissues } \\
\hline CK $7,13,14,19$ & Enamel organ \\
\hline CK 14 & $\begin{array}{l}\text { Most cells of enamel organ } \\
\text { (Odontogenic epithelial marker) }\end{array}$ \\
\hline CK 7 & Stellate reticulum and HERS \\
\hline CK 19 & $\begin{array}{l}\text { Preameloblasts and secretory } \\
\text { ameloblasts (secretory differentiation) }\end{array}$ \\
\hline CK 5/19 & Cell rests of Malassez \\
\hline
\end{tabular}

several diseases are attributable to abnormalities in KFAP (Pemphigus, Darier's disease, Dyskeratosis congenita). ${ }^{20}$ Common genetic disorders of keratin with oral involvement are briefed in Table $4 .{ }^{37-45}$

\section{ACQUIRED KERATIN DISORDERS}

Several oral disease processes demonstrate significant nongenetic abnormalities in keratinization. The most common are briefed in the Table 5. ${ }^{46-48}$

A thorough description of keratin from basics to disorders with oral implications is dealt with. The following part discusses the oral cytokeratins in specific, their expression patterns in normal and disease process. Also, highlighted is the diagnostic role of cytokeratins in the present era.

\section{SIGNIFICANCE OF CYTOKERATINS IN DIAGNOSTIC ORAL PATHOLOGY}

Cytokeratins demonstrate specific expression pattern which is site- specific and varies with the level of differentiation. This property of cytokeratin has evolved as a potential epithelial differentiation marker in cell biology, embryology and surgical pathology. Cytokeratins are the 'gold standard markers' in immunohistochemical diagnosis, classification and subtyping of carcinomas and detection of unclear metastasis. Soluble cytokeratin protein fragments detection is recently adopted as a tool to check tumor load and prognosis of carcinomas. ${ }^{49,50} \mathrm{~A}$ key characteristic of keratins that makes them useful in pathology is the relative stability of expression even after transformation to pathological states. ${ }^{7}$ Hence, selected cytokeratins along with other specific markers are the definitive diagnostic tools in current clinical pathology. ${ }^{1}$

Recently, it is been stated that cytokeratin expression is not restricted to carcinomas, few sarcomas with true epithelial differentiation (e.g.: synovial and epithelioid sarcomas) also are positive for specific cytokeratin types. ${ }^{51}$ Cytokeratins 7 and 19 are expressed by synovial sarcomas and cytokeratins 5/6 are specific for epithelioid sarcomas. ${ }^{52-54}$ Also, few specific nonepithelial tumors (smooth muscle tumors, melanomas and

Flow Chart 3: Working classification of oral keratin disorders

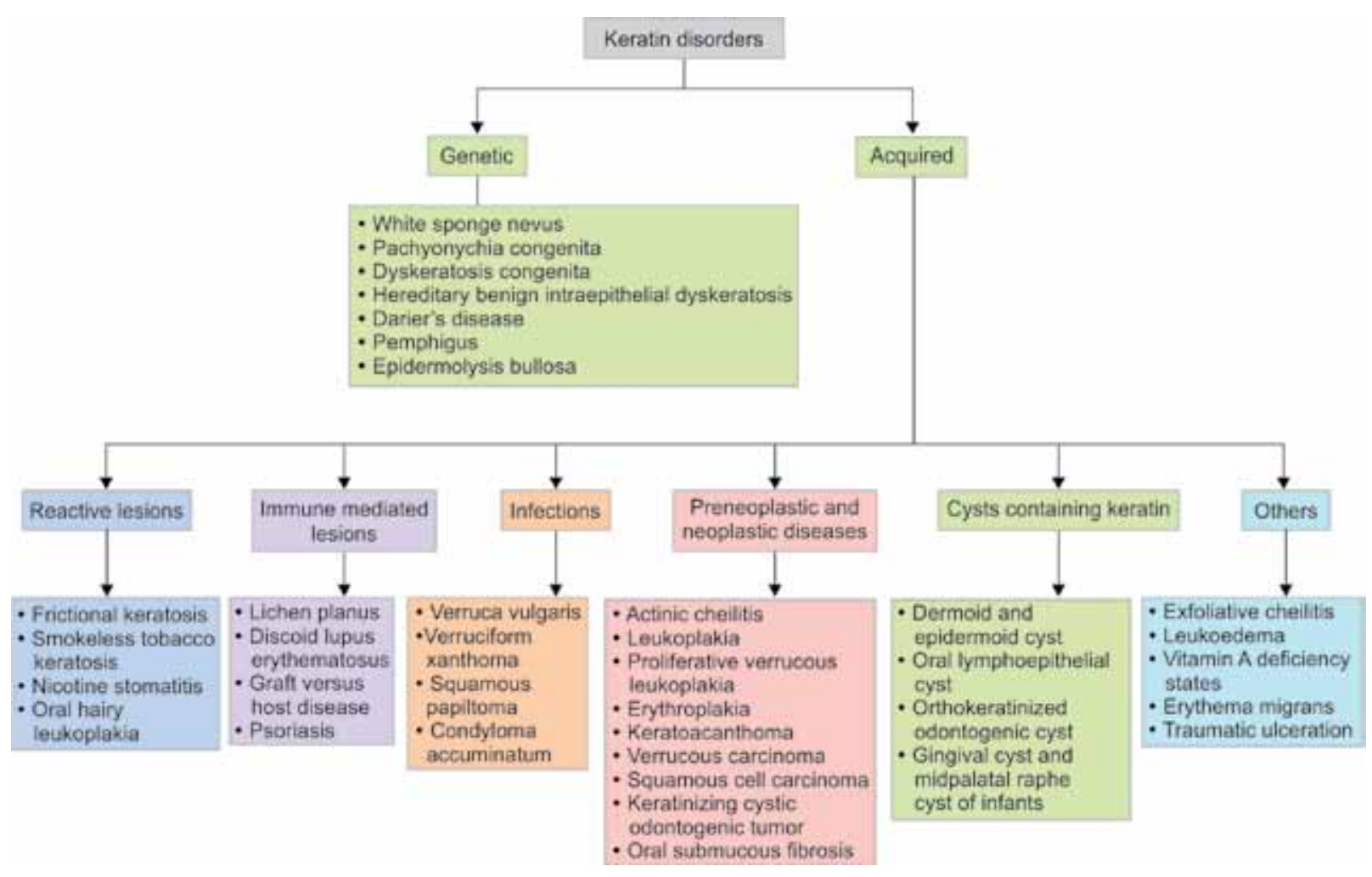


Table 4: Genetic disorders of keratin with significant oral manifestations

\begin{tabular}{|c|c|c|c|c|c|}
\hline \multirow[t]{2}{*}{ Disease } & \multirow[t]{2}{*}{ Defect } & \multicolumn{2}{|c|}{ Clinical features } & \multirow[t]{2}{*}{ Oral manifestations } & \multirow{2}{*}{$\begin{array}{l}\text { Histopathologic } \\
\text { features }\end{array}$} \\
\hline & & Site & Appearance & & \\
\hline $\begin{array}{l}\text { Epidermolysis bullosa } \\
\text { simplex }\end{array}$ & $\begin{array}{l}\text { K5 and } 14 \\
\text { autosomal dominant } \\
\text { inheritance }\end{array}$ & $\begin{array}{l}\text { Hands } \\
\text { and feet }\end{array}$ & $\begin{array}{l}\text { Blisters that } \\
\text { heal without } \\
\text { scarring }\end{array}$ & $\begin{array}{l}\text { Mucosal involvement } \\
\text { uncommon; mild } \\
\text { involvement- gingival } \\
\text { erythema, tenderness, } \\
\text { recession and } \\
\text { reduction in depth of } \\
\text { buccal vestibule }\end{array}$ & Intraepithelial clefting \\
\hline White sponge nevus & $\begin{array}{l}\text { K4/13 } \\
\text { Autosomal } \\
\text { dominant } \\
\text { inheritance }\end{array}$ & - & & $\begin{array}{l}\text { Asymptomatic, } \\
\text { symmetrical, thickened } \\
\text { white, corrugated } \\
\text { or velvety, diffuse } \\
\text { plaques affect buccal } \\
\text { mucosa bilaterally }\end{array}$ & $\begin{array}{ll}\text { - } & \text { Epithelial } \\
\text { hyperplasia and } \\
\text { hyperparakeratosis } \\
\text { - } & \text { Perinuclear } \\
\text { condensation } \\
\text { of keratin } \\
\text { tonofilaments in the } \\
\text { superficial layers of } \\
\text { epithelium }\end{array}$ \\
\hline \multirow[t]{2}{*}{ Pachyonychia congenita } & \multirow[t]{2}{*}{$\begin{array}{l}\mathrm{K} 6 \mathrm{~A}, \mathrm{~K} 6 \mathrm{~B}, \mathrm{~K} 6 \mathrm{C} \text {, } \\
\mathrm{K} 16 \text { or } \mathrm{K} 17 \\
\text { Autosomal } \\
\text { dominant } \\
\text { inheritance }\end{array}$} & Nails & $\begin{array}{l}\text { Free margins } \\
\text { get lifted due to } \\
\text { accumulation of } \\
\text { keratinaceous } \\
\text { material in nail } \\
\text { beds }\end{array}$ & \multirow[t]{2}{*}{$\begin{array}{l}\text { Hyperkeratosis of oral } \\
\text { mucosa }\end{array}$} & \multirow[t]{2}{*}{$\begin{array}{l}\text { Hyperparakeratosis } \\
\text { and acanthosis with } \\
\text { perinuclear } \\
\text { clearing of the epithelial } \\
\text { cells }\end{array}$} \\
\hline & & $\begin{array}{l}\text { Palmar } \\
\text { and } \\
\text { plantar } \\
\text { surfaces }\end{array}$ & Hyperkeratosis & & \\
\hline Dyskeratosis congenita & $\begin{array}{l}\text { DKC1 gene } \\
\text { Predominantly } \\
\text { X-linked recessive } \\
\text { inheritance }\end{array}$ & $\begin{array}{l}\text { Skin } \\
\text { Nail } \\
\text { Mucosa }\end{array}$ & $\begin{array}{l}\text { Abnormal } \\
\text { pigmentation } \\
\text { Dystrophy } \\
\text { Leukoplakia }\end{array}$ & $\begin{array}{l}\text { Leukoplakic lesions } \\
\text { on tongue, buccal } \\
\text { mucosa- one third } \\
\text { become malignant }\end{array}$ & $\begin{array}{l}\text { Hyperorthokeratosis } \\
\text { with epithelial atrophy } \\
\text { complication: } \\
\text { Progression to } \\
\text { squamous cell } \\
\text { carcinoma }\end{array}$ \\
\hline $\begin{array}{l}\text { Hereditary benign } \\
\text { intraepithelial } \\
\text { dyskeratosis }\end{array}$ & $\begin{array}{l}\text { HBID gene on } \\
\text { chromosome } 4 \\
\text { Autosomal } \\
\text { dominant } \\
\text { inheritance }\end{array}$ & Eye & $\begin{array}{l}\text { Elevated } \\
\text { epibulbar } \\
\text { plaques and } \\
\text { hyperemic } \\
\text { conjunctival } \\
\text { blood vessels }\end{array}$ & $\begin{array}{l}\text { Thick, corrugated } \\
\text { white plaques on } \\
\text { buccal and labial } \\
\text { mucosa }\end{array}$ & $\begin{array}{l}\text { Hyperparakeratosis } \\
\text { acanthosis and } \\
\text { dyskeratosis } \\
\text { (cell-within-a-cell } \\
\text { phenomenon) }\end{array}$ \\
\hline Darier's disease & $\begin{array}{l}\text { ATP2A2 gene } \\
\text { Autosomal } \\
\text { dominant } \\
\text { inheritance }\end{array}$ & $\begin{array}{l}\text { Skin of } \\
\text { trunk } \\
\text { and } \\
\text { scalp }\end{array}$ & $\begin{array}{l}\text { Numerous } \\
\text { erythematosus, } \\
\text { pruritic papules }\end{array}$ & $\begin{array}{l}\text { Asymptomatic multiple, } \\
\text { white, flat-topped } \\
\text { papules on hard palate } \\
\text { and alveolar mucosa- } \\
\text { may fuse to give a } \\
\text { cobblestone mucosal } \\
\text { appearance }\end{array}$ & $\begin{array}{l}\text { Dyskeratosis in the } \\
\text { form of corps and } \\
\text { grains, acantholysis, } \\
\text { elongated rete ridges }\end{array}$ \\
\hline Pemphigus & $\begin{array}{l}\text { Desmoglein 1and } 3 \\
\text { (HLA gene) }\end{array}$ & Skin & $\begin{array}{l}\text { Flaccid vesicles } \\
\text { and bullae } \\
\text { that rupture } \\
\text { to leave an } \\
\text { erythematosus, } \\
\text { denuded } \\
\text { surface }\end{array}$ & $\begin{array}{l}\text { Superficial ragged } \\
\text { erosions and } \\
\text { ulcerations anywhere } \\
\text { in oral cavity }\end{array}$ & $\begin{array}{l}\text { Acantholysis, } \\
\text { intraepithelial clefting } \\
\text { and basal layer of } \\
\text { cells resemble 'row of } \\
\text { tombstones' }\end{array}$ \\
\hline
\end{tabular}

endothelial cell tumors) may demonstrate anomalous cytokeratin expression in 'dot-like' pattern. Thus in any scenario, cytokeratins provide major clue to diagnosis. ${ }^{51}$

\section{Cytokeratin Expression in Oral Epithelial Pathology}

CK8 and CK18 are described as surrogate markers of malignant transformation in a squamous epithelium. In a study by Kanwar Deep Singh Nanda et al (2012), CK8 and CK 18 expression were absent in normal buccal mucosa, while intense expression was noted in dysplasia, OSF, and OSCC. This could be due to de novo expression of CK8 and CK18 in previously negative epithelium, which during malignant transformation might be regarded as a return to an embryonal expression pattern. ${ }^{55}$ 
Table 5: Acquired oral disorders of keratin

\begin{tabular}{|c|c|c|}
\hline Acquired keratin disorder & Oral manifestations & Keratin pathology \\
\hline \multicolumn{3}{|l|}{ Reactive lesions } \\
\hline Frictional keratosis & $\begin{array}{l}\text { Rough, white keratotic lesion in areas of mechanical } \\
\text { irritation }\end{array}$ & Hyperkeratosis \\
\hline $\begin{array}{l}\text { Smokeless tobacco } \\
\text { keratosis }\end{array}$ & $\begin{array}{l}\text { White plaque/distinct pouch on the mucosa in direct } \\
\text { contact with smokeless tobacco }\end{array}$ & Hyperkeratosis, parakeratin chevrons \\
\hline Nicotine stomatitis & $\begin{array}{l}\text { Diffusely grey/white palatal mucosa with numerous slightly } \\
\text { elevated papules with punctuate red centers }\end{array}$ & Hyperkeratinization \\
\hline Oral hairy leukoplakia & $\begin{array}{l}\text { Appearance ranges from faint white vertical streaks to } \\
\text { thickened and furrowed areas of leukoplakia often on lateral } \\
\text { border of tongue }\end{array}$ & $\begin{array}{l}\text { Hyperparakeratosis with surface } \\
\text { corrugations }\end{array}$ \\
\hline \multicolumn{3}{|l|}{ Immune mediated lesions } \\
\hline Lichen planus & $\begin{array}{l}\text { Asymptomatic, interlacing white lines on buccal mucosa } \\
\text { bilaterally is common (Whickham's striae) }\end{array}$ & Hyperkeratosis \\
\hline \multicolumn{3}{|l|}{ Infections } \\
\hline Verruca vulgaris & $\begin{array}{l}\text { Painless papule/nodule with papillary projections on } \\
\text { vermilli on border, labial mucosa or anterior tongue }\end{array}$ & Hyperkeratosis \\
\hline Verruciform xanthoma & $\begin{array}{l}\text { Painless, slightly elevated sessile nodule with papillary } \\
\text { surface on gingiva and alveolar mucosa }\end{array}$ & $\begin{array}{l}\text { Hyperparakeratosis with parakeratin } \\
\text { plugging }\end{array}$ \\
\hline \multicolumn{3}{|c|}{ Preneoplastic and neoplastic diseases } \\
\hline Actinic cheilitis & $\begin{array}{l}\text { Lip appears atrophic, finely wrinkled and swollen with } \\
\text { mottled areas of hyperpigmentation and with keratosis }\end{array}$ & Hyperkeratosis \\
\hline Leukoplakia & $\begin{array}{l}\text { Nonscrapable white patch on lip vermillion, buccal mucosa } \\
\text { and gingiva }\end{array}$ & Hyperkeratosis \\
\hline Erythroplakia & $\begin{array}{l}\text { Well demarcated erythematous macule or plaque with a soft, } \\
\text { velvety texture on floor of the mouth, tongue and soft palate }\end{array}$ & Lack of keratinization \\
\hline Keratoacanthoma & $\begin{array}{l}\text { Firm, nontender sessile nodule on vermillion } \\
\text { border of lips }\end{array}$ & $\begin{array}{l}\text { Dyskeratosis- individual cell } \\
\text { keratinization and keratin pearls } \\
\text { - Hyperkeratosis of surface } \\
\text { epithelium with keratin plugging }\end{array}$ \\
\hline Verrucous carcinoma & $\begin{array}{l}\text { Diffuse, white, painless thick plaque with verruciform surface } \\
\text { projections often corresponding to the site of chronic } \\
\text { tobacco placement }\end{array}$ & $\begin{array}{l}\text { Hyperkeratosis with parakeratin } \\
\text { plugging }\end{array}$ \\
\hline Squamous cell carcinoma & Nonhealing ulcer or exophytic growth & $\begin{array}{l}\text { Dyskeratosis- individual cell } \\
\text { keratinization and keratin pearls }\end{array}$ \\
\hline $\begin{array}{l}\text { Keratinizing cystic } \\
\text { odontogenic tumor }\end{array}$ & $\begin{array}{l}\text { Asymptomatic/painful swelling in the posterior body } \\
\text { and ascending ramus region }\end{array}$ & $\begin{array}{l}\text { Hyperparakeratosis, corrugated } \\
\text { surface keratin }\end{array}$ \\
\hline \multicolumn{3}{|l|}{ Others } \\
\hline Exfoliative cheilitis & $\begin{array}{l}\text { Persistent scaling and flaking of vermillion border of } \\
\text { the lips }\end{array}$ & $\begin{array}{l}\text { Excessive production and subsequent } \\
\text { desquamation of keratin }\end{array}$ \\
\hline
\end{tabular}

\section{Cytokeratin Expression in Salivary Neoplasms}

The CK profiling in salivary gland pathology has limited applications. Although non specific, the CKs help in delineating dual luminal-abluminal differentiation. ${ }^{56} \mathrm{~A}$ study by Nikolaos G Nikitakis et al (2004) revealed that MEC often express CK 7 in contrast to squamous cell carcinoma and salivary duct carcinoma showing a higher frequency of CK7/CK20 immunophenotype compared to the rest of malignant salivary gland tumors. ${ }^{57}$ Another study by Randall et al (2013) showed that CK 5/6 was specific for MEC and thus may be used as an adjunct in discriminating MEC from highly aggressive salivary duct carcinoma. ${ }^{58}$

\section{Cytokeratin Expression in Odontogenic Cysts}

Cytokeratin expression in odontogenic cysts namely odontogenic keratocyst (OKC), dentigerous cyst (DC) and radicular cysts have been extensively studied but no consistent differences have been noted. ${ }^{59}$ An interesting study by Smith and Matthews in 1991 revealed a strong expression of CK 1/10/11 by OKC, while DC and radicular cyst were negative. Also, a strong reaction of OKC lining for CK16 suggested its high proliferative activity. ${ }^{60}$ Yet other studies have also shown cytokeratin 16 expression in dentigerous and radicular cysts. ${ }^{59}$ Stoll et al in 2005 concluded that CK17 and 19 are valuable in distinguishing 
Table 6: Cytokeratin expression in odontogenic tumors

\begin{tabular}{ll}
\hline Cytokeratin & Expression \\
\hline CK 14 & $\begin{array}{l}\text { Adenomatoid Odontogenic tumor } \\
\text { (AOT) }\end{array}$ \\
CK 13, 14, 19 & Ameloblastoma \\
CK 14, CK 7*, CK 13*, & $\begin{array}{l}\text { Calcifying epithelial odontogenic } \\
\text { CK 19* }\end{array}$ \\
CK 13, CK 14, CK 7* & Ameloblastic fibroma \\
CK 7, 14 & Odontoma \\
\hline
\end{tabular}

*Expressed occasionally

OKCs from other odontogenic cysts (OKC with 93\% expression of CK17 and CK19 expression in contrast to DC and radicular cysts which showed $35 \%$ CK 17 positivity and $43 \%$ CK 19 positivity). ${ }^{61}$

\section{Cytokeratin Expression in Odontogenic Tumors}

Studies have revealed specific keratin expression in different odontogenic tumors (Table 6). ${ }^{33}$

\section{CONCLUSION}

An insatiable curiosity and appetite to explore the amazing world of oral cytokeratins widens the horizon in diagnostic pathology. Moreover, the field of cytokeratins is exhaustive and dynamic, but equally interesting. New cytokeratins and corresponding genes, their role as etiological factors, diagnostic markers as well as prognosticators are constantly being updated. Hence updating oneself with the new concepts is paramount.

\section{REFERENCES}

1. Moll R, Langbein MDL. The human keratins: biology and pathology. Histochem Cell Biol 2008;129:705-733.

2. Berkovitz BKB, Holland GR, Moxham BJ. Oral Anatomy, Histology and Embryology, 4th ed. Edinbergh: Elsevier limited 2009; p 223-252.

3. Pekny M, Lane EB. Intermediate filaments and stress. Exp Cell Res 2007;313:2244-2254.

4. Hofmeier J. Horn-lime plastic masses from keratin substances. German Pat. 1905;DE184915.

5. Bragulla HH, Homberger DG. Structure and functions of keratin proteins in simple, stratified, keratinized and cornified epithelia. J Anat 2009;214:516-559.

6. Presland RB, Dale BA. Epithelial structural proteins of the skin and oral cavity: Function in Health and Disease. Crit Rev Oral Biol Med 2000;11(4):383-408.

7. Oshima RG. Intermediate filaments: a historical perspective. Exp Cell Res 2007;313(10):1981-1994.

8. Nanci A. Ten Cate's oral histology, development, structure and function. 7th ed. Mosby, Missouri, 2008; pp 319-357.

9. Kumar GS. Orban's Oral histology and embryology, 12th ed. New Delhi:Elsevier 2008. pp 210-257.

10. Tudor D, Locke M, Owen-Jones E, Mackenzie IC. Intrinsic patterns of behavior of epithelial stem cells. J Investig Dermatol
Symp Proc 2004;9:208-214.

11. Dale BA, Salonen J, Jones AH. New approaches and concepts in the study of differentiation of oral epithelia. Crit Rev Oral Biol Med 1990;1(3):167-190.

12. Shapiro SS, Seiberg M, Cole CA. Vitamin A and its derivatives in experimental photo carcinogenesis: preventive effects and relevance to humans. J Drugs in Dermatology 2013;12(4): 458-463.

13. Irvine $A D, M c L e a n$ WHI. Human keratin diseases: the increasing spectrum of disease and subtlety of the phenotype-genotype correlation. British Journal of Dermatology 1999;140(5):815828.

14. Alberts B, Johnson A, Lewis J, Raff M, Roberts K, Walter P. Molecular biology of the cell, 4th ed. New York: Garland Science 2002; pp 924.

15. Garant PR. Oral cells and tissues. Ilinois: Quintessence Publishing Co., Inc. 2003; pp 89-100.

16. Lane EB, Mc Lean WH. Keratins and skin disorders. J Pathol 2004;204(4):355-366.

17. Parry DA, Strelkov SV, Burkhard P, Aebi U, Herrmann H. Towards a molecular description of intermediate filament structure and assembly. Exp Cell Res 2007;313(10):2204-2216.

18. Geisler N, Weber K. The amino acid sequence of chicken muscle desmin provides a common structural model for intermediate filament proteins. EMBO J 1982;1(12):1649-1656.

19. Kirfel J, Magin TM, Reichelt J, Keratins: A structural scaffold with emerging functions. Cellular and Molecular Life Sciences CMLS2003;60(1):56-71.

20. Strnad $P$, et al. Unique amino acid signatures that are evolutionarily conserved distinguish simple-type, epidermal and hair keratins. J Cell Science 2011;124(24):4221-4232.

21. Shetty S, Gokul S. Keratinization and its disorders. Oman Medical Journal 2012;27(5):348-357.

22. Steinert PM. Structure, function and dynamics of Keratin intermediate filaments. The Journal of Investigative Dermatology 1993;100 (6):729-734.

23. Green KJ, Bohringer M, Gocken T, Jones JCR. Intermediate Filament Associated Proteins. Advances in Protein Chemistry 2005;70:143-202.

24. Schweizer J, et al. New consensus nomenclature for mammalian keratins. J Cell Biol 2006;174:169-174.

25. Gu LH, Coulombe PA. Keratin function in skin epithelia: A broadening palette with surprising shades. Current Opinion in Cell Biology 2007;19:13-23.

26. Surekharamulu, Kale AD, Hallikerimath S, Kotrashetti V. Comparing modified Papanicolaou stain with Ayoub-Shklar and Haematoxylin-Eosin stain for demonstration of keratin in paraffin embedded tissue sections. J Oral Maxillofac Pathol 2013;17(1):23-30.

27. Bancroft JD, Cook HC, Stirling RW. Manual of histological techniques and their diagnostic application. New York: Churchill Livingstone, 1994; p 419-420.

28. Pearse AGE. The histochemical demonstration of Keratin by methods involving selective oxidation. Quarterly J Microscopical Science 1951;92(4):393-402.

29. Moll R, Franke WW, Schiller DL, Geiger B, Krepler R. The catalog of human cytokeratins: patterns of expression in normal epithelia, tumors and cultured cells. Cell 1982:31(1):11-24.

30. Fraser RD, MacRae TP, Parry DA, Suzuki E. Intermediate filaments in alpha-keratins. Proc Natl Acad Sci USA 1986;83: 1179-1183. 
31. Coulombe PA, Bousquet O, Ma L, Yamada S, Wirtz D. The 'ins' and 'outs' of intermediate filament organization. Tr Cell Biol 2000; 10:420-428.

32. Lindberg K, Rheinwald JG. Three different keratinocyte subtypes identified in human oral epithelium by their patterns of keratin expression in culture and in xenografts. Differentiation 1990; 45:230-241.

33. Crivelini MM, de Araújo VC, de Sousa SO, de Araújo NS. Cytokeratins in epithelia of odontogenic neoplasms. Oral Dis 2003;9(1):1-6.

34. Dardick I. Color atlas/ text of salivary gland tumor pathology. New York: Igaku- Shoin Medical Publishers, inc. 1996; p 7-9.

35. Geiger $\mathrm{S}$, et al. Cytokeratin polypeptide expression in different epithelial elements of human salivary glands. Virchows Arch A 1987;410:403-414.

36. Draeger A, et al. Cytokeratins, smooth muscle actin and vimentin in human normal salivary gland and pleomorphic adenomas. APMIS 1991;99(1-6):405-415.

37. Neville BW, Damm DD, Allen CM, Bouquot JE. Oral and Maxillofacial Pathology, 3rd. ed. Missouri: Saunders 2009;p 362-423, 741-794.

38. McLean, et al. Keratin 16 and keratin 17 mutations cause pachyonychiacongenita. Nat Genet 1995;9:273-278.

39. Bowden PE, Haley JL, Kansky A, Rothnagel, JA, Jones DO, Turner RJ. Mutation of a type II keratin gene (K6a) in pachyonychia congenita. Nat Genet 1995;10:363-365.

40. Smith FJD, et al. A mutation in human keratin K6b produces a phenocopy of the K17 disorder pachyonychia congenita type 2. Hum Mol Genet 1998;7:1143-1148.

41. Wilson NJ, et al. Keratin K6c mutations cause focal palmoplantar keratoderma. J Invest Dermatol 2010;130:425-429.

42. Dokal I, Vulliamy T, Mason P, Bessler M. Clinical utility gene card for: Dyskeratosis congenita. European Journal of Human Genetics 2011:19.

43. Cummings TJ, Dodd LG, Eedes CR, Klintworth GK. Hereditary benign intraepithelial dyskeratosis: an evaluation of diagnostic cytology. Arch Pathol Lab Med 2008;132:1325-1328.

44. Sakuntabhai A, et al. Mutations in ATP2A2, encoding a $\mathrm{Ca}_{2}+$ pump, cause Darier disease. Nat Genet 1999;21(3):271-277.

45. Grando SA. Pemphigus autoimmunity: Hypotheses and realities. Autoimmunity 2012;45(1):7-35.

46. Rajendran R, Sivapathasundharam B. Shafer's textbook of oral pathology. 6th ed. Noida: Elsevier, 2009:p 80-117.

47. Regezi JA, Sciubba JJ, Jordan RC. Oral pathology: clinical pathologic correlations. 5th ed. St. Louis, Missouri: Saunders, 2008;p 73-98.
48. Warnakulasuriya S, Tilakaratne WM. Oral medicine and pathology: a guide to diagnosis and management, 1st ed. New Delhi, India: Jaypee Brothers Medical Publishers, 2014; p 269-320.

49. Barak V, Goike H, Panaretakis KW, Einarsson R. Clinical utility of cytokeratins as tumor markers. Clin Biochem 2004;37(7):529540.

50. Linder S. Cytokeratin markers come of age. Tumour Biol 2007; 28(4):189-195.

51. Weiss SH, Goldblum JR. Enzingerand Weiss's Soft tissue tumors. 5th ed. Philadelphia, USA: Mosby Inc., 2008; pg 131-135.

52. Miettinen M, Fanburg-Smith JC, Virolainen M, Shmookler BM, Fetsch JF. Epithelioid sarcoma: An immunohistochemical analysis of 112 classical and variant cases and a discussion of the differential diagnosis. Hum Pathol 1999;30(8): 934-942.

53. Laskin WB, Epithelioid MM. sarcoma: New insights based on an extended immunohistochemical analysis. Arch Pathol Lab Med 2003;127(9):1161-1168.

54. Smith TA, Machen SK, Fisher C, Goldblum JR. Usefulness of cytokeratin subsets for distinguishing monophasic synovial sarcoma from malignant peripheral nerve sheath tumor. Am J Clin Pathol 1999;112(5):641-648.

55. Nanda KDS, Ranganathan K, Devi U, Joshua E. Increased expression of CK8 and CK18 in leukoplakia, oral submucous fibrosis, and oral squamous cell carcinoma: an immunohistochemistry study. Oral Surg Oral Med Oral Pathol Oral Radiol 2012;113:245-253.

56. Fletcher CDM. Diagnostic histopathology of tumors, 3rd ed. Philadelphia, USA: Elsevier 2007;1:p 239-326.

57. Nikitakis $\mathrm{NG}$, et al. Immunohistochemical expression of cytokeratins 7 and 20 in malignant salivary gland tumors. Modern Pathology 2004;17:407-415.

58. Butler RT, Spector ME, Thomas D, McDaniel AS, McHugh JB. An Immunohistochemical Panel for Reliable Differentiation of Salivary Duct Carcinoma and Mucoepidermoid Carcinoma. Head and Neck Pathology. September 2013;1-8.

59. Shear M, Speight P. Cysts of oral and maxillofacial regions. 4th ed. Oxford, UK: Blackwell Munksgaard 2007; p 38-43.

60. Smith AJ, Matthews JB. Odontogenic epithelium and its residues. In: Browne RM, editors. Investigative Pathology of the Odontogenic Cysts, Boca Raton: CRC Press 1991;53-85.

61. Stoll C, Stollenwerk C, Riedeger D, Mittermeyer C, Alfer J. Cytokeratin expression patterns for distinction of odontogenic keratocysts from dentigerous and radicular cysts. J Oral Pathology and Medicine 2005;34:558-564. 